DOI: https://doi.org/10.36910/6775-2524-0560-2020-41-07

УДК: 004.9

${ }^{1}$ Кузьмич Олена Іванівна, к. ф.-м. н., доцент

https://orcid.org/0000-0002-8717-4497

1Яковлюк Сергій Миколайович, студент

${ }^{1}$ Багнюк Наталія Володимирівна, к. т. н., доцент

https://orcid.org/0000-0002-7120-5455

${ }^{2}$ Мекуш Оксана Григорівна

https://orcid.org/0000-0001-6052-9211

${ }^{1}$ Луцький національний технічний університет,

${ }^{2}$ Волинський національний університет імені Лесі Українки, м. Луцьк, Україна

\title{
ДОСЛІДЖЕННЯ ЕФЕКТИВНОСТІ МОБІЛЬНОГО ДОДАТКУ-ТРЕНАЖЕРА ДЛЯ ВИВЧЕННЯ АНГЛІЙСЬКОЇ МОВИ
}

Кузьмич О.І., Яковлюк С.М., Багнюк Н.В., Мекуш О.Г. Дослідження ефективності мобільного додаткутренажера для вивчення англійської мови. В даній статті представлено проект розробки мобільного додатку-тренажера для вивчення англійської мови базового рівня, а також результати проведених досліджень його ефективності у формі опитувань та контрольованих експериментів.

Ключові слова: додаток, іноземна мова, навчання.

Е.И. Кузьмич С.Н. Яковлюк, Н.В. Багнюк, О.Г. Мекуш. Исследование эффективности мобильного приложения-тренажера для изучения английского языка. В данной статье представлен проект разработки мобильного приложения-тренажера для изучения английского языка базового уровня, а также результаты проведенных исследований его эффективности в форме опросов и контролируемых экспериментов.

Ключевые слова: приложение, иностранный язык, обучение.

O.I. Kuzmych, S.M. Yakovliuk, N.V. Bahniuk, O.G. Mekush. Kesearch of the effectiveness of a mobile simulator application for learning English. This article presents a project for the development of a mobile simulator application for learning basic English, as well as the results of studies of its effectiveness in the form of surveys and controlled experiments.

Keywords: application, foreign language, education.

\section{Постановка наукової проблеми.}

В сучасному світі дуже швидко зростає необхідність володіння декількома мовами, серед яких особливе місце посідає англійська, оскільки вона має інтернаціональний статус і в більшості країн світу є однією 3 державних мов. Особливого значення ій надає і те, що сучасний інформаційнотехнологічний світ 3 початку його становлення, активно реалізовувався носіями цієї мови. Завдяки представленим фактам виникає необхідність вчити англійську мову всім, хто планує працювати із іноземцями або подорожувати світом. В контексті цього особливого значення набуває ефективний, швидкий та оперативний процес вивчення мови саме дітьми, як майбутніми активними членами цього суспільства.

Сьогодні англійська мова, як основна мова міжнародного спілкування, викладається у переважній більшості шкіл по всьому світу, зокрема, й в Україні. Іноді ії викладання буває занадто ускладнене для учнів, що викликає у них відторгнення та, як наслідок, небажання навчатись. Також частою причиною такого ставлення до навчання у школі $є$ несприятлива обстановка та велика кількість людей у класі. Представлені дані показують необхідність створення технологічного засобу для дітей, за допомогою якого вони могли б зручно та без перешкод вивчати іноземну мову, і при цьому не залишатимуться в залежності від шкільного класу або певних часових рамок. Як відомо, сьогодення характеризується високою доступністю технологічних пристроїв, зокрема, й для дітей. Враховуючи це, можна прийти до висновку, що засіб, який би відповідав представленим вимогам це мобільний додаток, аналіз ефективності та практична розробка якого представлено в цій статті.

Мобільні платформи наразі дуже розповсюджені і за даними Pew Research Center у 2017 році смартфон був у $59 \%$ дорослих людей. Більш того, цей показник в рази вищий у країнах розвинутих у сфері інформаційних технологій. Насьогодні можна помітити, що практично у кожного школяра ще у початкових класах з'являється їх перший смартфон. Проте, найпопулярнішими програмами для смартфонів у дітей залишаються ігрові додатки, месенджери та додатки соціальних мереж. Одразу зрозуміло, що складніші додатки у дітей не викликають зацікавленості саме завдяки ускладненості та незрозумілості. Тому головними вимогами до навчальних мобільних додатків для дітей $є$ саме інтуїтивна зрозумілість та простота інтерфейсу без нагромадження зайвої інформації.

Аналіз досліджень. 
Проблема вивчення іноземних мов часто піднімається у педагогічних науках. Дослідження методів та інших теоретичних засад вивчення іноземних мов представлені у роботах В. В. Осадчого, С.В. Симоненка, С.В. Смоліної, Р. Горбатюка, Ю. Тулашвілі та інших $[1,2,3]$.

Також існує багато робіт у сфері інформаційних технологій щодо розробки програм та засобів для вивчення англійської мови Використання мобільних застосунків у навчанні іноземним мовам досліджували Ю-Чанг Хсу, Ю-Хі Чінг, Дж. Аттевел, Дж. Тракслер, Б. Ріордан $[4,5]$. Були наведені проекти власних розробок лінгвістико-аналітичного спрямування на тему застосування комп'ютерних пристроїв для навчання у роботах Л. В. Горбатюк, Н. В. Кравченко, Г. М. Алєксєєвої, Т. С. Розумної, П. А. Пеха, Н. Н. Касаткіної, Н. С. Лагутіної, С. В. Варшавської $[6,7,8,9]$.

Також були розглянуті перспективи розвитку мобільних застосунків для вивчення іноземних мов та формування іншомовної компетенції в роботах Квинг-Ке Фу, Гво-Жен Кванг, Р.С. Гуревича, С. В. Тітова, А. П. Аваменко, Л. В. Горбатюк, Н. В. Кравченко, Г. М. Алєксєєвої, Т.С. Розумної [10, $11,12]$.

Таким чином, мобільні пристрої пропонують широкі можливості для організації персоналізованих занять з іноземної мови, що визначає актуальність та важливість представленого дослідження. Робота зі смартфонами й планшетами на занятті з іноземної мови дає змогу працювати 3 автентичними матеріалами, спонукає учнів та студентів до творчості, мобільності, гнучкості в мисленні [9].

Виклад основного матеріалу й обгрунтування отриманих результатів.

Мобільні додатки, зазвичай, набагато простіші від десктопних програм, оскільки мають менше функцій та в цілому повинні вмістити інформацію на значно меншому просторі екрану, що вимагає лаконічності та логічної упорядкованості інформації. Одним з правил дизайну мобільних додатків, особливо, якщо основною аудиторією користувачів $\epsilon$ діти, $є$ простота інтерфейсу та достатня кількість функцій.

Таким чином, в межах розробленого практичного проекту був спроектований простий та лаконічний інтерфейс, а сама структура програми представлена на рисунку 1.

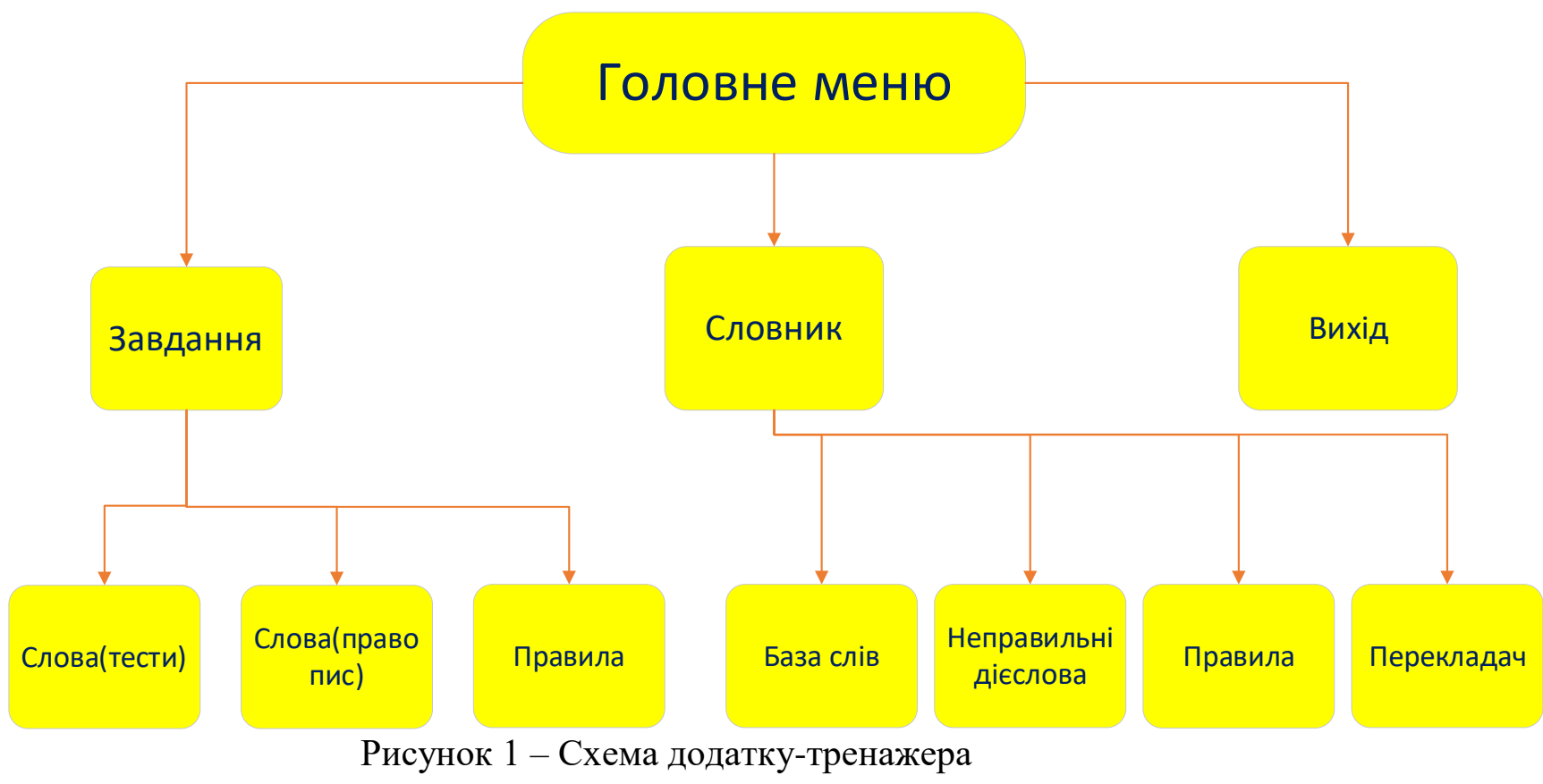

Під час проектування мобільного додатку-тренажера було обрано декілька типів тестування, а також було розроблено довідник з підібраною навчальною базою: словами та правилами, які вивчатимуться за допомогою програми, та деякими базовими довідниковими даними.

Для використання у додатку було розроблено три типи тестування:

1. Закриті тестові завдання на переклад слів;

2. Відкриті тестові завдання на переклад слів;

3. Закриті тестові завдання на граматику.

Також було обрано довідникову базу, до якої відносяться:

1. База слів, представлених для вивчення;

2. Таблиця-довідник неправильних дієслів англійської мови; 
3. Граматичні правила побудови речень англійською мовою.

Крім вищевказаного було вирішено додати до застосунку можливість посилатись до певного інтернет-ресурсу задля перекладу слів та фраз.

\section{Особливості розробки навчального додатку-тренажера}

Головною частиною додатку є тестові завдання різних типів та рівнів складності, два 3 яких застосовуються для розширення словникового запасу учнів та один для покращення володіння граматичними правилами.

Тестові завдання закритого типу на переклад слів представляють собою запитання у вигляді ілюстрації та слова, яке іiі визначає, українською мовою. Також присутні 4 варіанти відповіді англійські слова, одне з яких є перекладом представленого у запитанні слова. (Рис. 2, а)
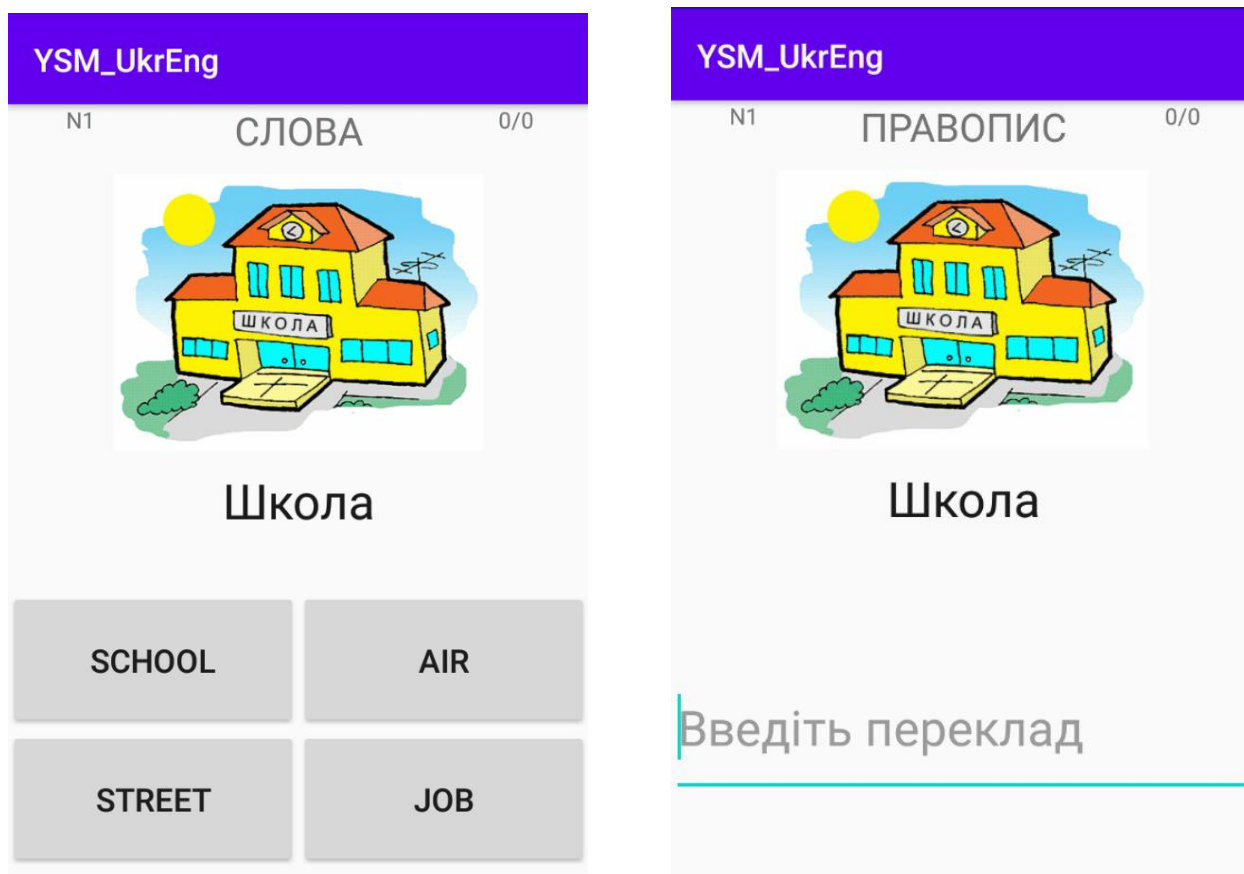

\section{Введіть переклад}

ДАЛІ

ДАЛІ

Рисунок 2 - Тестові завдання на переклад слів(скріншоти з додатку): а) закрита форма; б) відкрита форма.

Наступним типом тестових завдань $є$ ті ж самі питання та відповіді, проте, без представлення варіантів відповідей, а тільки зі стрічкою вводу (Рис. 2, б).

Третім типом тестових завдань, який представлений у даному додатку є завдання закритої форми на граматику. Головною їі функцією є тестування на тему часових форм англійської мови (Present Simple, Past Continuous тощо). Завдання представляє собою запитання у вигляді речення із пропущеним словом, а серед відповідей присутні слова, які можливо підставити на місце пропуску. При цьому лише один з варіантів вірний (Рис. 3). 


\section{YSM_UkrEng \\ N1 ГРАМАТИКА going to school}

(Я йду до школи)

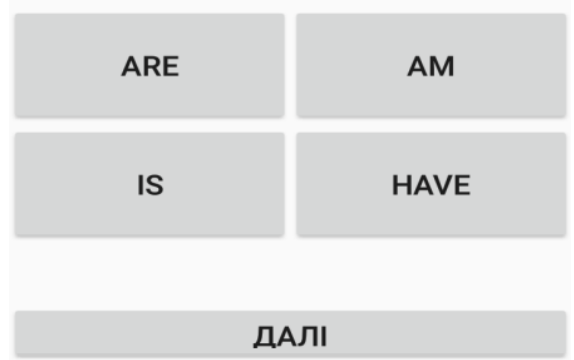

Рисунок 3 - Тестове завдання закритої форми на граматику (скріншот 3 додатку)

Дослідження ефективності розробленого додатку-тренажера

В процесі аналітичного дослідження предметної області було досліджено ефективність додатку за допомогою соціологічного опитування та контрольованого експерименту.

Так за результатами опитування користувачів додатку (Рис. 4) стало зрозуміло, що в цілому додаток добре сприймається респондентами та має хорошу потенційну корисність в якості ефективного додатку-тренажера для навчання дітей іноземної мови. Для опитування було підібрано 5 питань на які повинні були відповісти респонденти для оцінювання загальної якості розробленого продукту:

1. Оцінка загального враження;

2. Оцінка потенційної корисності;

3. Оцінка зручності;

4. Оцінка інтерфейсу;

5. Оцінка розроблених тестів.

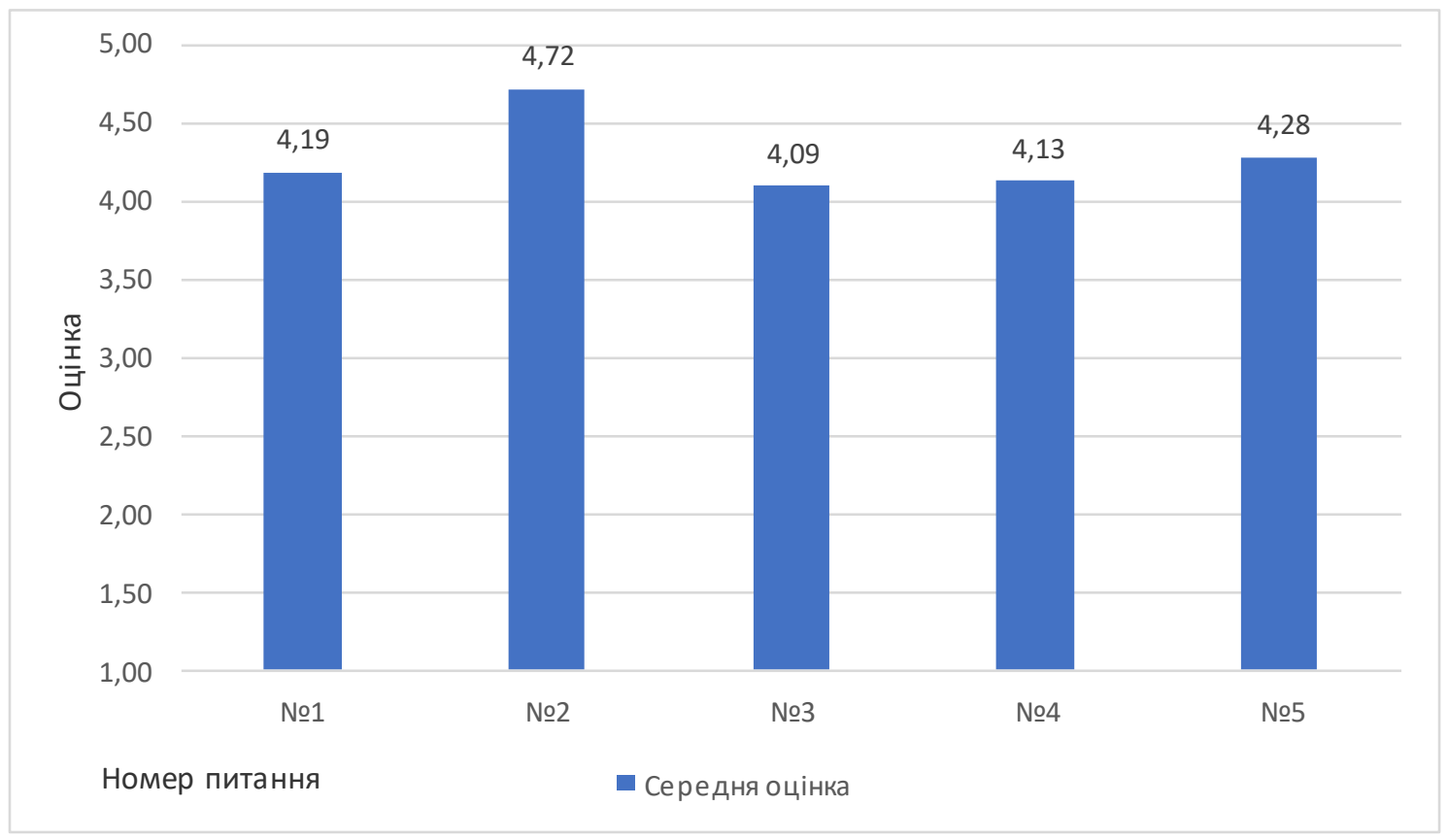

Рисунок 4 - Результати опитування користувачів додатку 
Також для оцінки ефективності було проведено контрольований експеримент із 30 учасниками - учнями початкових та середніх класів. Частково результати проведених експериментів представлені на рисунках 5 та 6.

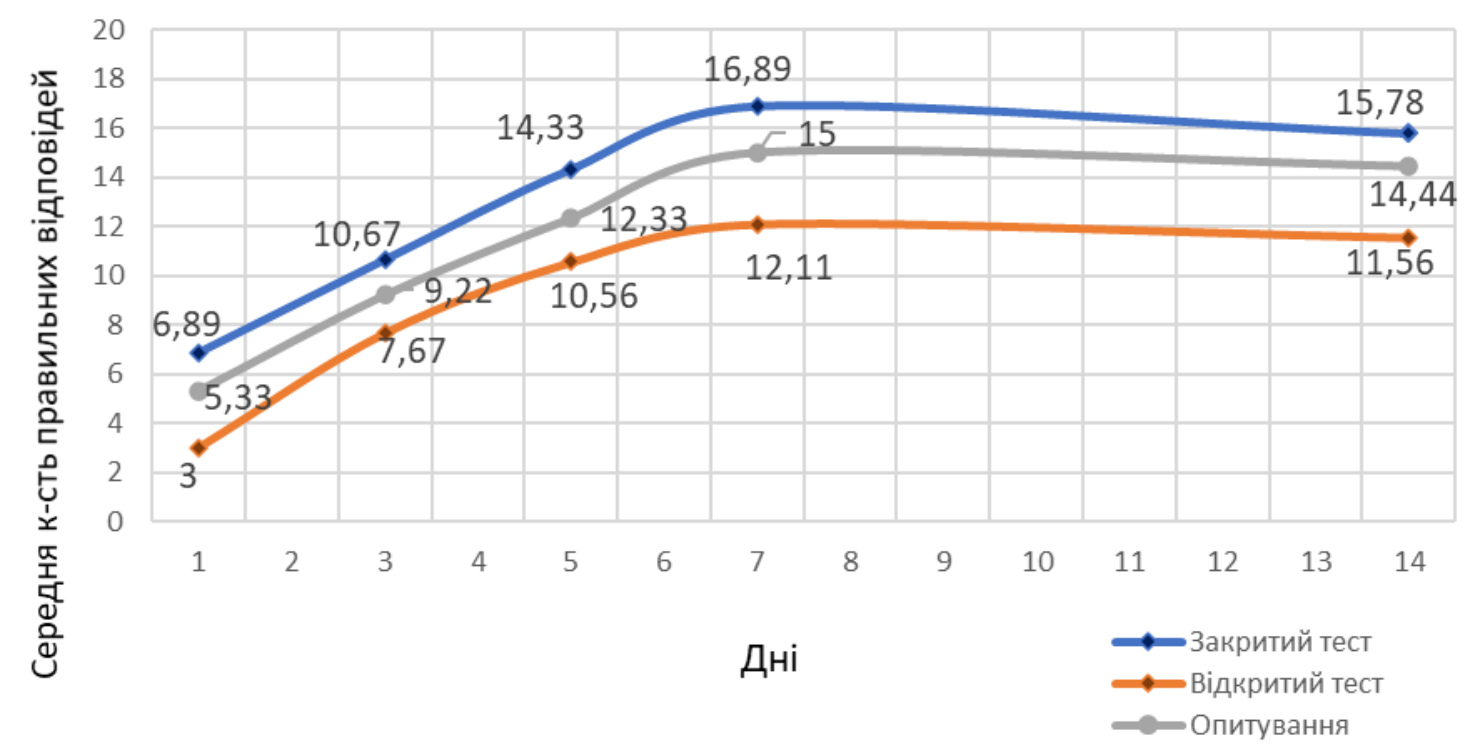

Рисунок 5 - Результати експерименту із тестами на переклад

Для проведення експерименту було відведено 14 днів. Впродовж перших 7-ми днів учасники проходили відповідні тестування із добіркою в 20 тестів на переклад слів та 10 тестів на граматику за допомогою додатку. Далі, починаючи 3 8-го дня учасники припиняли користуватися додатком $\mathrm{i}$ наприкінці, 14-го дня знову проходили усі тестування. Також паралельно проводилось усне опитування учасників експерименту під час якого правильними вважались усі відповіді які схожі на правильний переклад, не беручи до уваги дефекти в вимові даних слів.

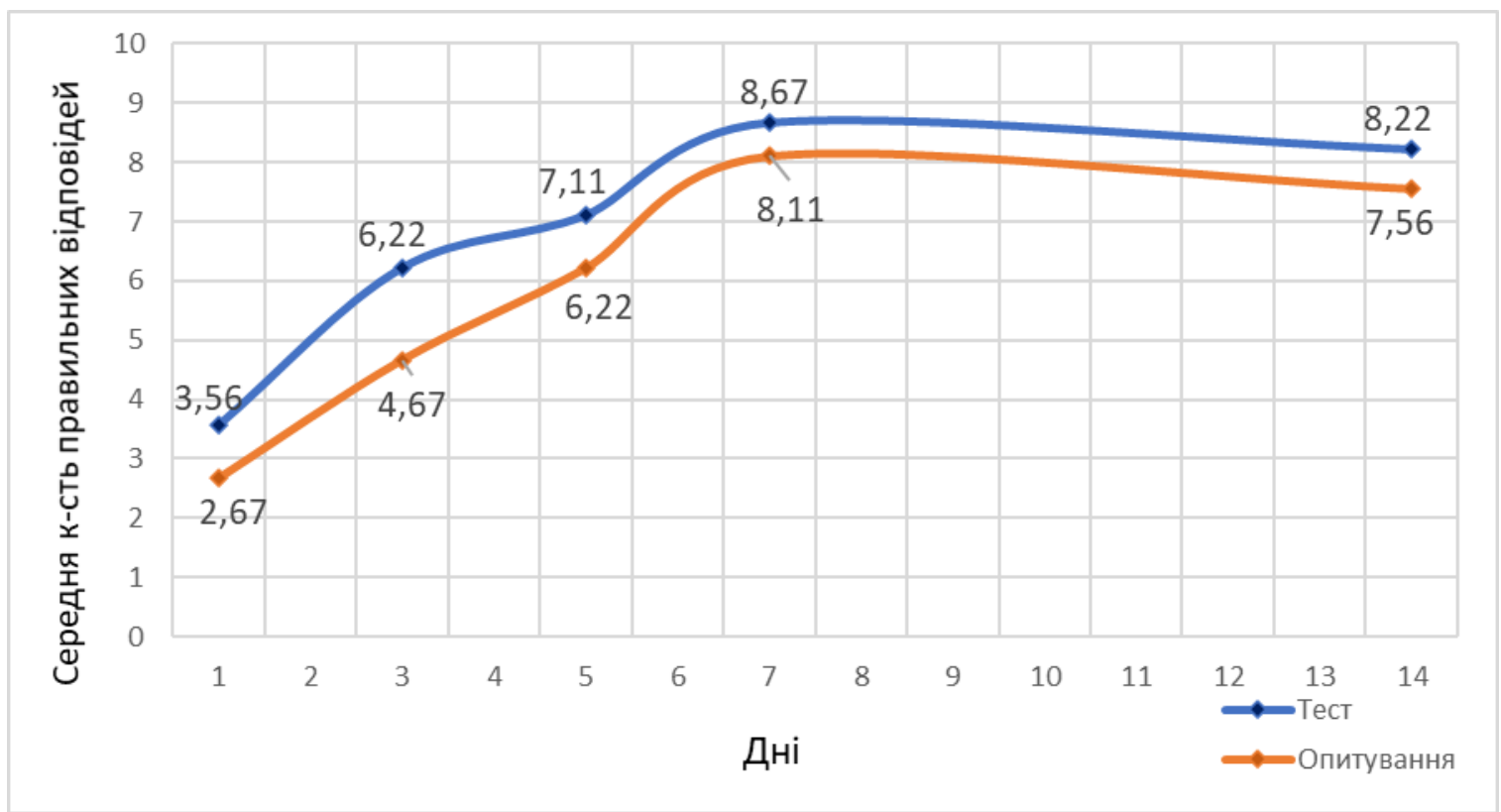

Рисунок 5 - Результати експерименту із тестом на граматику

Всі реалізовані модельні експерименти показали хороші результати ефективності розробленого додатку та, зокрема, якості самих тестів.

Учасники запам'ятали в середньому 9,11 слів із 14,67 незнайомих, а також навчилися правильно писати 8,56 слів із 17 , які вони раніше не могли правильно відтворити у письмовому вигляді.

За результатами експерименту з тестом на граматику, кількість правильних відповідей через опитування зросла з $26,7 \%$ до $75,6 \%$ на довгостроковому рівні.

Висновки та перспективи подальшого дослідження. 
У роботі був представлений проект додатка-тренажера, який пропонується як засіб для вивчення англійської мови базового рівня. Даний додаток добре оцінили користувачі, які брали участь в опитуванні. Також проведені дослідження довели, що розроблений застосунок показує хорошу ефективність для вивчення та запам'ятовування слів та правил англійської мови учням початкових та середніх класів. Перспективами розвитку даного додатку є покращення та розширення навчальної бази та удосконалення ефективності навчання за допомогою використання результатів найновіших досліджень. Подальші дослідження у представленому напрямку можуть відобразити шляхи можливого вдосконалення розробленого додатку-тренажера і стануть запорукою подальшого його покращення в напрямку розширення та модифікації функціоналу додатку.

Список бібліографічного опису.

1. В. В. Осадчий, С. В. Симоненко, «Іноземна мова як засіб формування комунікативної компетентності майбутніх інженерів-програмістів», Інформаційні технології і засоби навчання, №. 58, Вип. 2, с. 38-48, 2017.

2. Р. Горбатюк, Ю. Тулашвілі, «Мобільне навчання як нова технологія вищої освіти», Науковий вісник Ужгородського національного університету. Серія: Педагогіка. Соціальна робота, № 27, с. 31-34, 2013

3. С. В. Смоліна, «Методика формування іншомовної лексичної компетенції», Іноземні мови, № 4, с. 16-23, 2010.

4. Yu-Chang Hsu, Yu-Hui Ching, «Mobile App Desing for Teaching and Learning Educators», Experiences in an Online Graduate Course, Vol 14, № 4, pp.117-139, 2013.

5. J. Attewell, J. Traxler, B. Riordan, C. Dennett «Towards sustainable large-scale implementation of mobile learning: a mobile learning network (MoLeNET). In the bridge from text to context», Conference materials mLearn, 2008, c. 28-35, 2008.

6. Л. В. Горбатюк, Н. В. Кравченко, Г. М. Алєксєєва, Т. С. Розумна «Мобільні додатки як засоби формування іншомовної лексичної компетентності студентів нефілологічних спеціальностей», Інформаційні технології і засоби навчання, Том 74 № 6, с. 150-164, 2019

7. П. А. Пех, С. М. Яковлюк «Створення колоди карток з програмування мовою С++ засобами програми Аnki», Комп'ютерно інтегровані технології: освіта, наука, виробництво, с. 172-176, 2019

8. Н. Н. Касаткина, Н. С. Лагутина, «Разработка компьютерных программ как инструмент повышения качества обучения иностранному языку», Информационно-коммуникационные технологии в лингвистике, лингводидактике и межкультурной коммуникации, с.124-132, 2014.

9. С. В. Варшавская, «Использование мобильных справочных приложений для оптимизации процесса обучения английскому языку», Новые технологии в обучении иностранным языкам, с. 97-103, 2015.

10. Fu, Qing-Ke, and Gwo-Jen Hwang. «Trends in mobile technology-supported collaborative learning: A systematic review of journal publications from 2007 to 2016.» Computers \& Education, № 119, 129-143, 2018.

11. Р. С. Гуревич, «Мобільне навчання - нова технологія професійної освіти XXI століття» Вісник Луганського національного університету імені Тараса Шевченка. Педагогічні науки, 20, 113-119, 2012. ISSN: $2076-8184$. Інформаційні технології і засоби навчання, 2019, Том 74, №6.

12. С. В. Титова, А. П. Авраменко, «Эволюция средств обучения в преподавании иностранных языков: от компьютера к смартфону», Вестник Московского университета., №. 1. Серия 19: Лингвистика и межкультурная коммуникация, c. 9-21, 2013.

\section{References:}

1. V.V. Osadchy, S.V. Symonenko, "Foreign language as a means of forming the communicative competence of future software engineers", Information technology and teaching aids, No.58, Issue. 2, p. 38-48, 2017.

2. R. Gorbatyuk, Y. Tulashvili, "Mobile learning as a new technology of higher education", Scientific Bulletin of Uzhgorod National University. Series: Pedagogy. Social work,No. 27, p. 31-34, 2013.

3. S.V. Smolina, "Methods of forming foreign language lexical competence", Foreign languages,No. 4, p. 16-23, 2010.

4. Yu-Chang Hsu, Yu-Hui Ching, «Mobile App Desing for Teaching and Learning Educators», Experiences in Online Graduate Course, Vol 14, No. 4, pp.117-139, 2013.

5. J. Attewell, J. Traxler, B. Riordan, C. Dennett «Towards sustainable large-scale implementation of mobile learning: a mobile learning network (MoLeNET). In the bridge from text to context », Conference materials mLearn, 2008, p. 28-35, 2008.

6. L.V. Gorbatyuk, N.V. Kravchenko, G.M. Alekseeva, T.S. Rozumna, "Mobile applications as a means of forming foreign lexical competence of students of non-philological specialties", Information technology and teaching aids, Vol. 74, No. 6, pp. 150-164, 2019.

7. P.A. Pekh, S.M. Yakovlyuk "Creating a deck of cards for programming in $\mathrm{C}++$ by means of the Anki program", Computer-integrated technologies: education, science, production, pp. 172-176, 2019.

8. N.N. Kasatkina, N.S. Lagutina, "Development of computer programs as a tool to improve the quality of foreign language learning", Information and communication technologies in linguistics, linguodidactics and intercultural communication, pp.124-132, 2014.

9. S.V. Varshavskaya, "The use of mobile reference applications to optimize the process of learning English", New technologies in foreign language teaching, pp. 97-103, 2015.

10. Fu, Qing-Ke, and Gwo-Jen Hwang. «Trends in mobile technology-supported collaborative learning: A systematic review of journal publications from 2007 to 2016.» Computers \& Education, № 119, 129-143, 2018.

11. R.S. Gurevich, "Mobile learning - a new technology of vocational education of the XXI century" Bulletin of Lugansk National University named after Taras Shevchenko. Pedagogical Sciences, 20, 113-119, 2012. ISSN: $2076-8184$. Information Technologies and Teaching Aids, 2019, Volume 74, No. 6.

12. S.V. Titova, A.P. Avramenko, "Evolution of teaching aids in foreign language teaching: from computer to smartphone", Bulletin of Moscow University, No.1. Series 19: Linguistics and Intercultural Communication, pp. 9-21, 2013. 